\title{
A MITOLOGIA DOS ORIXÁS EM AULAS DE BACIAS HIDROGRÁFICAS: O ENSINO E OS DIÁLOGOS SOBRE INTOLERÂNCIA RELIGIOSA
}

\author{
Wellington Gabriel de Borba \\ Secretaria de Estado da Educação, Cultura e Esportes de Goiás \\ (SEDUCE-GO), Goiânia, Goiás, Brasil
}

\begin{abstract}
Resumo: Este artigo narra um conjunto de aulas de Geografia para o Ensino Fundamental em uma escola pública, cujo tema central envolveu o conteúdo das bacias hidrográficas aos seguintes temas transversais: mitologia dos orixás, religiões de matriz africana e intolerância religiosa. Os objetivos intentavam aliar a literatura ao ensino de bacias hidrográficas, especificamente, usando contos sobre os orixás e ao fomento de diálogos sobre os referidos temas transversais, privilegiando o respeito e a tolerância religiosa na escola. Houve uma revisão da produção acadêmica, da legislação, de documentos normativos e reportagens acerca do tema, como também do livro didático e do livro Mitologia dos Orixás (Prandi, 2018). Pode se constatar que a literatura, através dos contos, potencializou as aulas de Geografia, reforçando os conceitos sobre bacias hidrográficas e abrindo espaço para a discussão dos temas transversais.
\end{abstract}

Palavras-chave: Bacias Hidrográficas. Mitologia dos Orixás. Religião de Matriz Africana. Intolerância Religiosa.

\section{INTRODUÇÃO}

Este trabalho narra uma experiência pedagógica envolvendo aulas de Geografia que tiveram como conteúdo as bacias hidrográficas e, de forma transversal, a mitologia dos orixás, as religiões de matriz africana e a intolerância religiosa. Além da leitura do livro didático, de um texto complementar e de mapas, as aulas englobaram também a leitura de contos extraídos da obra científica e literária Mitologia dos Orixás, de Reginaldo Prandi (2018). O público foi uma turma de $7^{\circ}$ Ano do Ensino Fundamental, da Escola Estadual Jardim Novo Mundo, localizada no bairro homônimo da periferia de Goiânia - GO, e o planejamento teve como finalidade as atividades escolares referentes ao Dia da Consciência Negra, comemorado todo dia 20 de novembro, cuja abordagem na educação básica é estabelecida pela Lei Federal 10.639, de 09 de janeiro de 2003. A inspiração foi uma vivência em um terreiro de Candomblé, no qual foram vistos inseridos naquele espaço religioso alguns ex-alunos que na antiga escola se assumiam como evangélicos.

Para a redação deste artigo, houve uma revisão da legislação brasileira para que fosse delimitada a atuação do professor e resguardada a sua ação pedagógica em caso de eventuais pressões antagônicas ao que foi tratado durante as aulas. Essa revisão foi citada no anexo do plano de aula elaborado e entregue à Coordenação Pedagógica. Houve também uma revisão bibliográfica, sendo esta dividida em dois momentos. 
O primeiro serviu para inspirar o planejamento das aulas delimitando que as mesmas envolveriam problematizações, debate e leitura de documentos (CAMPOS, 2015), que foram substituídos pela literatura (MARTINZ, 2017) através dos contos da Mitologia dos Orixás (PRANDI, 2018). Serviu também para compreender que estudantes praticantes de religiões de matriz africana se assumem com outras identidades, evangélicos no caso, como forma de se resguardarem contra atos discriminatórios que se voltam contra as suas reais religiões (CAMPOS, 2015). Ainda nesta etapa, houve a revisão do livro didático (ADAS, M., ADAS, S., 2015b), para identificar potencialidades e limitações e, por fim, a leitura da Mitologia dos Orixás (PRANDI, 2018), para a seleção dos contos com potencial pedagógico para o tema das aulas.

O segundo momento serviu para a edição do artigo em si, pois conferiu maior robustez aos conceitos e entendimentos. São eles as bacias hidrográficas, a origem e as diferenças entre as religiões de matriz africanas, especificamente, o Candomblé e a Umbanda, a natureza e a diversidade dos atos de intolerância religiosa, bem como as origens, a diversidade, as histórias, os poderes e como se inserem os orixás nos panteões das religiões afro-brasileiras. Desta revisão houve uma expansão para documentos normativos do Ministério da Educação e da Secretaria de Educação de Goiás, além de reportagens cujas citações objetivam situar cotidianamente o que é citado em nível acadêmico por este texto.

Após a revisão, realizou-se a redação do planejamento das aulas, ou seja, a divisão do tempo em aulas e o estabelecimento de objetivos, conteúdos, metodologias e avaliações. As aulas foram aplicadas conforme o planejamento e as percepções organizadas e discorridas aqui.

Os objetivos são evidenciar que a lei exige e respalda o professor ao trabalhar conteúdos relacionados à África e aos afro-brasileiros, porém ainda assim existe muita oposição ao trabalho pedagógico e assédio ao professor quando esses conteúdos envolvem a religião. Demonstrar como o conteúdo referente às bacias hidrográficas pode ser pertinente ao fomentar discussões envolvendo a mitologia dos orixás, as religiões de matriz africana e a intolerância religiosa. Por fim, expor como a literatura, através do livro de contos Mitologia dos Orixás (PRANDI, 2018), pode atuar como elo entre os conteúdos na medida em que reforça o conteúdo recorrente, bacia hidrográfica, e que traz os até então pouco abordados, os temas transversais.

\section{A PESQUISA E O PLANEJAMENTO DAS AULAS}

A provocação para esta pesquisa partiu de uma constatação ao visitar um terreiro de Candomblé no qual estavam presentes alguns ex-alunos de uma antiga escola, anterior à escola campo, na qual eram comuns as situações em que esses alunos cantavam hinos evangélicos, dando a entender que eram protestantes. No entanto, no terreiro os estudantes estavam vestidos a caráter. Eles transitavam e interagiam com as pessoas dali com bastante naturalidade. Também conheciam os espaços, os símbolos e os valores, ou seja, realizavam ações e tinham aspectos de quem estava integrado há muito tempo ao grupo existente naquele espaço religioso. Sendo assim, esses aspectos sugeriram que os 
BORBA, W. G.

alunos talvez temessem sofrer na escola ataques de intolerância religiosa, uma vez que são do Candomblé.

De acordo com Prandi (2004), o Candomblé surgiu no século XIX na Bahia como uma forma de resistência dos escravos africanos e mais tarde dos afro-brasileiros. $O$ culto é voltado para a adoração dos Orixás e de outras divindades africanas. Já a Umbanda surgiu no estado do Rio de Janeiro, no início do século XX, e tem características do kardecismo e do catolicismo, como os santos, as orações e os cânticos. No culto, além dos orixás africanos, são adoradas as divindades caboclas. Ambas de matriz africana e vítimas de ataques de intolerância religiosa, ou seja, de discursos, violências, invisibilidades, propagação de ideias cujo objetivo é impedir que tais religiões existam, entre outros (SILVA, 2007).

Os ataques de intolerância são variados e vários autores reconhecem neles um viés racista, velado, que perdura há séculos em nível institucional e social, uma vez que essas religiões são assimiladas como ligadas aos negros, grupo contra o qual se volta o racismo no Brasil (CAMPOS, 2015; HALLEY, 2014; LIMA et al., 2016; PAULO, 2015; PRANDI, 2004; SILVA, 2007; SUPERINTERESSANTE, 2018; TEIXEIRA, 2009). Silva (2007) cita invasões e depredações de terreiros, acusações de sequestro de crianças para sacrifício em rituais satânicos, bem como de fieis com exigência de conversão para o cristianismo, a contratação de carros de som para anunciar em frente aos terreiros os horários dos cultos em igrejas evangélicas da vizinhança, pressões para que o Poder Público remova nomes e símbolos de orixás em locais públicos, passeatas contra a existência de terreiros, entre outras situações. Desde que surgiram as religiões de matriz africanas, seus seguidores são vítimas de intolerância religiosa (PRANDI, 2004).

Não diferente disso, a partir dos anos 1960 e em razão do surgimento das igrejas neopentecostais, os atos de intolerância, muitas vezes em nível de palácios e câmaras governamentais, vem se intensificando (SILVA, 2007) no que outros autores chamam de a "guerra santa praticada por algumas igrejas evangélicas" (LIMA et al., 2016, p. 715). Essa guerra santa, além de racista, é decorrente de uma concorrência religiosa empreendida por algumas igrejas neopentecostais e que tem por objetivo conseguir novos fiéis assediando os fiéis das religiões de terreiro. As igrejas neopentecostais se estabelecem como detentoras da verdade, da cura e do bem, enquanto as demais são sujas, mentirosas e adoradoras do Diabo (SILVA, 2007).

Além da discrição dos estudantes quanto à manifestação de suas identidades, ou seja, de que são praticantes do Candomblé, a localização do terreiro visitado, na última rua do bairro em meio a várias chácaras, deu a entender que aquele é um espaço marginalizado e invisibilizado e que tal localização pode ser uma estratégia de defesa do mesmo. Em um levantamento cartográfico e histórico envolvendo os terreiros de Xangô em Recife - PE até o começo da década de 1930, Halley (2014, p. 23) informa:

Conforme observado, a partir do advento do regime do Estado Novo, a cidade do Recife presencia profundas transformações no seu tecido engendradas pela introdução de reformas urbanas calcadas na modernização e "higienização" dos bairros centrais, que tinham, entre outros objetivos, a erradicação dos mocambos, e o controle e repressão aos centros afro-religiosos. Em face deste contexto, os adeptos das religiões afro-brasileiras do rio Água Fria acabaram por elaborar e reelaborar estratégias territoriais frente ao cenário de controle e repressão étnicoreligioso da época. 
Em outra pesquisa, dessa vez considerando os terreiros de Candomblé na cidade de Goiânia - GO, Teixeira (2009, p. 31) afirma que o

terreiro de Candomblé em Goiânia se constituiu como um território-terreiro onde a dimensão social de sua paisagem aparece de forma desigual em relação aos espaços produzidos pelas religiões cristãs, ou seja, os seguidores das religiões afro-brasileiras não têm as mesmas condições de consumir a cidade como os seguidores cristãos.

Essas repressões e desigualdades contra as de religiões de matriz africana são noticiadas cotidianamente. Uma reportagem da Revista Super Interessante (2008) cita agressões como pedradas, invasões e quebradeiras aos terreiros localizados nas favelas do Rio de Janeiro - RJ. Essas invasões, quando acontecem, são determinadas por traficantes evangélicos e culminam na expulsão dos frequentadores dos terreiros (SUPER INTERESSANTE, 2018). Os ataques de intolerância também envolvem a escola, na qual tornam difícil abordar temas relacionados à história e à cultura afro-brasileiras quando estes envolvem as influências religiosas da África. Abrem assim precedentes para processos administrativos contra os docentes que trabalham o conteúdo em favor da legislação e a despeito da vontade de pais e diretores (LIMA et al., 2016). Também fazem com que os estudantes prefiram esconder suas religiões, conforme narra um professor:

Quando falei em África alguns começaram a dizer que lá era terra da macumba e aí tive que entrar no assunto [...] ficou um menino na sala que veio falar comigo enquanto eu desmontava o data show, e ele disse que era de Candomblé, filho de Santo, mas que não era pra ninguém ficar sabendo. (Professor 5 - Escola C) (PAULO, 2015, p. 75-76).

Além da problemática envolvendo a dificuldade dos estudantes de religiões de matriz africana se assumirem como tal na escola e dos professores poderem abordar o assunto, o dia da Consciência Negra, em 20 de novembro, contou como mais um motivo para tratar em sala de aula sobre os orixás, as divindades adoradas no Candomblé e na Umbanda, e com isso discutir e expor aspectos das religiões de matriz africana e incentivar nos estudantes um conjunto de ideias e atitudes de tolerância para com essas e outras religiões minoritárias.

Na escola campo, após um diagnóstico, que consistiu em perguntar e levantar a mão para responder, a maioria dos estudantes se declarou evangélica de denominações pentecostais e neopentecostais. Por outro lado, a grande parcela restante se declarou católica. Além disso, existia na escola também um grupo de missionárias evangélicas que desenvolviam um trabalho social com a autorização da gestão. Logo, eventuais malentendidos podiam acontecer e deviam ser considerados, inclusive porque alguns segmentos da sociedade são contra abordar na escola temas como a religião'. A partir disso, tornou-se importante uma pesquisa sobre a legislação brasileira e a referenciação da mesma no plano de aula e agora para este trabalho.

O Brasil é um país laico no qual a liberdade de culto é garantida desde a primeira constituição republicana (BRASIL, 1891). Nos dias de hoje, a Constituição Federal de 1988 estabelece a liberdade religiosa no artigo $5^{\circ}$, que garante também diversos outros direitos 
individuais, entre eles a igualdade perante a lei e as liberdades de pensamento, reunião e divulgação de ideias (BRASIL, 1988). A educação, no artigo $6^{\circ}$ da Constituição Federal, é definida como um direito social de todos e que:

Art. 205. A educação, direito de todos e dever do Estado e da família, será promovida e incentivada com a colaboração da sociedade, visando ao pleno desenvolvimento da pessoa, seu preparo para o exercício da cidadania e sua qualificação para o trabalho (BRASIL, 1988).

No que se refere ao ensino, por sua vez:

Art. 206. O ensino será ministrado com base nos seguintes princípios:

I - igualdade de condições para o acesso e permanência na escola;

II - liberdade de aprender, ensinar, pesquisar e divulgar o pensamento, a arte e o saber;

III - pluralismo de idéias e de concepções pedagógicas, e coexistência de instituições públicas e privadas de ensino (BRASIL, 1988).

A Lei Federal 9.394, de 20 de dezembro de 1996, defende que:

Art. $3^{\circ} \mathrm{O}$ ensino será ministrado com base nos seguintes princípios:

I - igualdade de condições para o acesso e permanência na escola;

II - liberdade de aprender, ensinar, pesquisar e divulgar a cultura, o pensamento, a arte e o saber;

III - pluralismo de ideias e de concepções pedagógicas; IV - respeito à liberdade e apreço à tolerância; [sem grifo no original] (BRASIL, 1996).

Os Parâmetros Curriculares Nacionais, publicados pelo Ministério da Educação, também são uma importante referência para a educação brasileira, pois influenciam os currículos das secretarias de educação, os livros didáticos, os projetos políticos pedagógicos, as aulas dos professores, etc. Neles são trazidos diversos temas transversais para todas as disciplinas obrigatórias nos currículos escolares. No que se refere à Geografia, entre os temas transversais, podemos destacar a ética e a pluralidade de ideias e a orientação de que a disciplina deve fomentar em suas aulas as noções de respeito, tolerância e o senso de igualdade e justiça entre os estudantes (BRASIL, 1998, p. 42-43).

Além da legislação, as experiências de outros autores foram importantes. Campos (2015), por exemplo, descreve as aulas de Língua Portuguesa que lecionou para uma turma de $8^{\circ}$ ano do Ensino Fundamental em um colégio público em Goiás - GO. Essas aulas tiveram como perspectivas a identidade cultural e a liberdade de culto, que envolve inclusive a liberdade de manifestá-lo. A autora realizou um diagnóstico na turma para identificar entre os alunos as experiências fundamentadas nas memórias coletivas de suas famílias e do povo de sua cidade, permitindo tocar no ponto da invisibilidade em relação às religiões de matriz africana, em especial, aos terreiros existentes há séculos na cidade e que foram fundados pelos escravos negros. Os alunos foram incentivados a debater situ- 
ações cotidianas de racismo e preconceito, vivenciadas pelos próprios estudantes e contra as religiões de matriz africana. Tendo em vista esse diálogo, a autora propôs como atividade aos seus estudantes a análise de documentos históricos expondo ideias discriminatórias contra as religiões de matriz africana e finaliza produzindo com os alunos um novo debate sobre a liberdade religiosa (CAMPOS, 2015).

Já Martins (2017) faz considerações sobre as transformações urbanas ocorridas na Rússia ao final do século XIX. Discorre sobre as mudanças nos aspectos sociais, políticos e econômicos acontecidos naquele país durante o período que marca o fim do feudalismo e a transição para o capitalismo. Tudo isso décadas após as outras potências europeias migrarem para o capitalismo industrial com trabalho livre, para o fim das monarquias absolutistas dando lugar às repúblicas e às monarquias constitucionais e, por fim, para a urbanização da sociedade. Para realizar essa pesquisa, a autora utilizou como fonte contextualizada a obra de ficção "Os Irmãos Karamazov" de Fiódor Dostoievski e assinalou que a Literatura é um vasto campo na obtenção de informações importantes para a Geografia, devendo com isso ser melhor aproveitada pelos geógrafos ao realizarem suas pesquisas.

Tendo em vista a experiência pedagógica e a sugestão de pesquisa dada pelas respectivas autoras (CAMPOS, 2015; MARTINS, 2017), foi desenvolvida na escola do Jardim Novo Mundo uma sequência pedagógica baseada na leitura de quatro contos encontrados no livro Mitologia dos Orixás (PRANDI, 2018). Essa obra reúne mais de 300 contos que discorrem sobre os orixás, que o próprio autor descreve como as figuras divinas do Candomblé, e servem de parâmetro teológico para os cultos religiosos do Candomblé e para os seus fiéis. Entretanto, Prandi (2018) salienta que esses contos são tradicionalmente transmitidos de maneira oral entre os fiéis dos terreiros, característica que torna difícil um melhor acesso e uma melhor compreensão a respeito das crenças dessa religião.

A academia, no decorrer de décadas, tem-se dedicado a decupar e descrever o Candomblé, em especial, os mitos a respeito dos orixás. Com isso, o livro Mitologia dos Orixás é uma compilação do que foi produzido academicamente no decorrer de décadas de pesquisa e uma forma de divulgação mais acessível da teologia do Candomblé. Também o resultado sistematizado da compilação de pesquisas lideradas pelo autor e promovidas com rigor científico. Reginaldo Prandi é professor na Universidade de São Paulo e contou com apoio público à pesquisa. Assim, mesmo que os contos assumam um aspecto literário, neste caso em forma de poemas, a origem das informações neles contidas e o rigor com que foram escritos atendem aos aspectos científicos (PRANDI, 2018).

O livro didático de Geografia adotado na escola e distribuído pelo MEC através do Programa Nacional do Livro Didático - PNLD também foi parte da bibliografia das aulas. A obra pertence à coleção Expedições Geográficas de Melhem Adas e Sérgio Adas e foi publicada em 2015 pela Editora Moderna (ADAS, M., ADAS, S., 2015b). Os conteúdos dos livros estão razoavelmente adequados para o $7^{\circ}$ ano tendo em vista o Currículo de Referência da Rede Estadual de Goiás em sua versão experimental. De acordo com o documento, os conteúdos do $7^{\circ}$ ano do Ensino Fundamental têm como objetivo o estudo do Brasil, abordando para isso os aspectos físicos de seu território e os aspectos humanos 
(GOIÁS, 2011, p. 199-203). O aproveitamento do livro se deu, porém, quanto aos mapas usados para as atividades de cartografia envolvendo as bacias hidrográficas, principalmente o referente à região Centro-Oeste (ADAS, M., ADAS, S., 2015b, p. 248).

Os conteúdos sobre bacias hidrográficas são abordados no volume referente ao $6^{\circ}$ ano. Contudo, eles são apresentados de maneira muito simples e, para os objetivos das aulas planejadas, são insuficientes. No livro do $6^{\circ}$ ano falta, por exemplo, o conceito para as bacias hidrográficas (ADAS, M., ADAS, S., 2015a), cabendo ao professor fazer a conceitualização. No caso, uma bacia hidrográfica é a região drenada por um corpo d'água, como um córrego ou um rio, de maneira direta ou indireta, através de um afluente. Esse conceito pode ser encontrado nas citações de Bergmann e Pedrozo (2008).

Por outro lado, o livro do $7^{\circ}$ ano contempla conteúdos a respeito da história e da cultura dos afro-brasileiros, conforme manda a Lei Federal 10.639/03 (BRASIL, 2003). No "Percurso 8 - Brasil: a diversidade cultural e os afro-brasileiros" ${ }^{2}$, os autores dizem que ao todo três grandes grupos étnicos deram origem ao povo brasileiro, sendo os negros um deles. Os negros tiveram como origem três grandes grupos culturais na África (Figura 1) e foram trazidos para ser escravizados no Brasil, o principal destino do tráfico negreiro internacional entre os séculos XVI e XIX.

Figura 1 - Mapa com o qual os autores situam os grandes grupos culturais que dos quais partiram os negros escravizados no Brasil

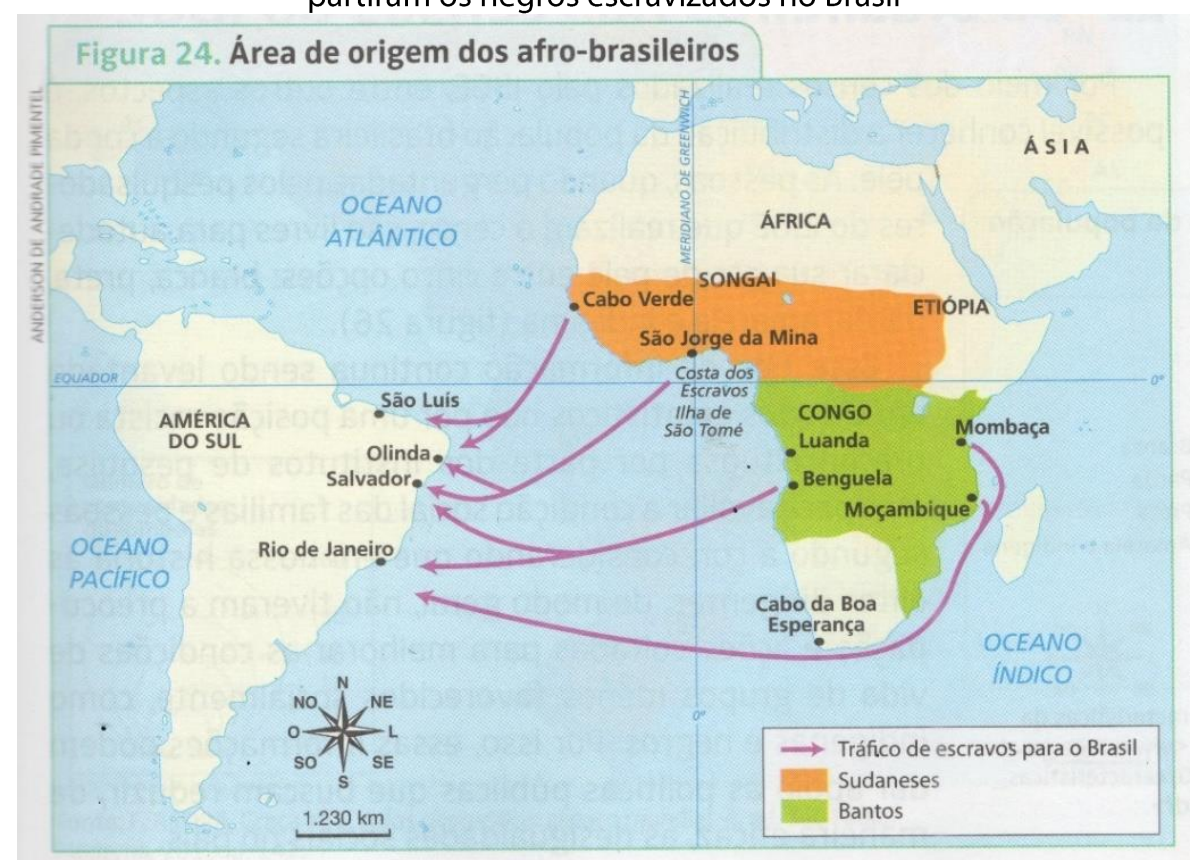

Fonte: ADAS, M., ADAS, S., Expedições Geográficas. $7^{\circ}$ Ano. Editora Moderna. São Paulo, 2015b, p. 67.

A escravidão, por sua vez, foi extremamente violenta, sendo ilustrada por um quadro de Jean-Baptiste Debret (Figura 2). Os autores citam também dados estatísticos atuais sobre os afro-brasileiros. Diferenciam cor, termo utilizado pelo Instituto Brasileiro 
de Geografia e Estatística (IBGE), e raça, termo utilizado pelos estudos sociais. Situam os negros como a maioria da população brasileira e sobre a qual recai a maior parte da desigualdade socioeconômica existente no Brasil. Por fim, eles citam os movimentos de articulação política dos negros no Brasil, o $R A P^{3}$ como uma expressão cultural de resistência e as lutas por ações afirmativas. No entanto, nada é falado sobre o aspecto religioso, principalmente, acerca das religiões de matriz africana, nem mesmo nos exercícios de fixação, cujos autores costumam trazer textos e reportagens envolvendo atualidades para direcionar as perguntas (ADAS, M.; ADAS, S., 2015b, p. 66-73).

Figura 2 - Aplicação do castigo do Açoite (1834)

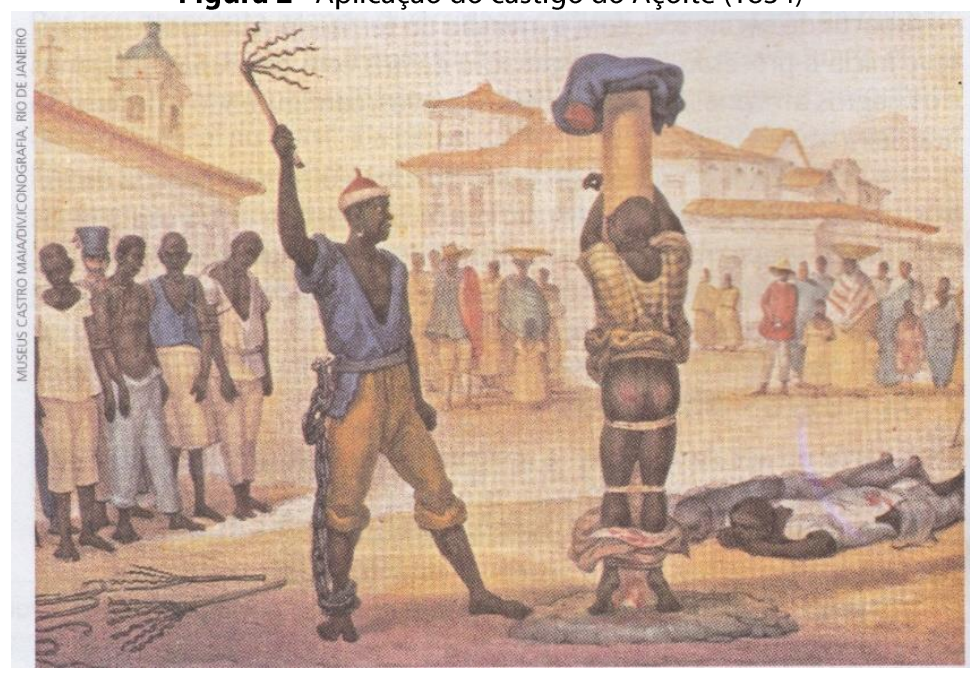

Fonte: ADAS, M., ADAS, S., Expedições Geográficas. 70 Ano. Editora Moderna. São Paulo, 2015, p. 68. Autor: DEBRET, Jean-Baptiste (1768-1848)

\section{AS AULAS: O PROCESSO DE ENSINO-APRENDIZADO}

Após a revisão da legislação, foi elaborado um planejamento quinzenal envolvendo seis aulas de 50 minutos de duração cada uma. O plano envolveu um texto sobre as bacias hidrográficas e com conceitos como o de nascente, foz, afluente, subafluente etc. Também com considerações sobre os aspectos ambientais e socioeconômicos relativos às bacias, que, por sua vez, desencadearam aspectos referentes à preservação ambiental e às formas de exploração sustentável dos mananciais. Junto foi editado um mapa para que nas cópias os estudantes identificassem e colorissem as bacias hidrográficas e pontos como nascentes, afluentes e subafluentes, entre outros. Por fim, redigidos exercícios de fixação para responder no caderno e selecionados quatro contos de orixás para leitura em sala de aula e para discussões a respeito das religiões de matriz africana, da intolerância religiosa e das bacias hidrográficas. 
BORBA, W. G.

As aulas aconteceram conforme o planejamento. $O$ texto envolvendo os conceitos sobre bacias hidrográficas foi lido, discutido e pontuado. As cópias do mapa foram entregues aos alunos e em sua maioria preenchidas e coloridas adequadamente. Os exercícios de fixação foram respondidos e a correção foi feita na lousa com a participação oral dos estudantes. Por fim, houve a leitura dos contos, etapa que foi iniciada com uma piada regional envolvendo o Rio Paranaíba, que divide os territórios dos estados de Goiás e de Minas Gerais ${ }^{4}$. Depois, foi feita aos estudantes a apresentação do livro Mitologia dos Orixás (PRANDI, 2018), na qual foi descrita a breve biografia do autor, Reginaldo Prandi, e a forma como ele realizou a pesquisa para escrever o livro. Também pontuada a importância da obra para o conhecimento e para o combate ao preconceito religioso. Então, os estudantes foram informados que seriam lidos alguns contos do livro cujo enredo pudesse ser relacionado aos rios, pois esses contos serviriam para entender como as culturas e as religiões compreendem os mesmos, fornecendo perspectivas diferentes das científicas.

Os estudantes ficaram curiosos, porém, ao ser exposto que algumas religiões acreditam no poder dos orixás, surgiram alguns cochichos polêmicos e que serviram para questioná-los se sabiam o que é um orixá e se sabiam quais são as religiões que neles acreditam. Houve falas com ideias preconceituosas e jocosas ${ }^{5}$, além de muito desconhecimento. Sendo assim, foram pontuados alguns aspectos. Primeiro, a macumba é o nome de um instrumento de percussão surgido na África e trazido pelos escravos. Um desenho (esboço) do instrumento foi feito na lousa e a maneira de tocar simulada com as mãos. Segundo, que as religiões tratadas apenas como macumba são diferentes entre si, exemplo do Candomblé e da Umbanda. Uma diferenciação breve e acessível foi feita aos estudantes, porém embasada no que pode ser encontrado em Prandi (2004). Pacificados esses pontos, foi explicado que além de diferentes entre si, as religiões como o Candomblé e a Umbanda acreditam no poder dos orixás, sendo estes divindades que conectam os seres humanos ao deus supremo e criador, Olorum na língua iorubá, que protegem e abençoam as pessoas que neles acreditam e que cada orixá tem poderes e características específicas (PRANDI, 2004, 2018).

A exposição desses pontos embasou um debate junto aos estudantes, permitindo alertar sobre os exemplos de falas preconceituosas que são ditas contra as religiões de matriz africana. Pontuar que na sala provavelmente havia colegas dessas religiões e que essas pessoas estão por toda parte, inclusive várias delas na escola, entre os estudantes, entre os professores etc. Que algumas dessas pessoas podiam ser o vizinho, um parente querido ou até o melhor amigo, mas que as falas preconceituosas fazem com que essas pessoas prefiram esconder suas identidades religiosas. A aula acabou e a leitura dos contos ficou para a próxima.

$\mathrm{Na}$ aula seguinte, os estudantes continuavam curiosos e isso serviu para reforçar algumas ideias da aula anterior, como a de que macumba é um instrumento musical, que existem várias religiões de matriz africana e que elas são diferentes umas das outras, que existem falas preconceituosas contra os seus seguidores etc. A partir daí, foi iniciada a leitura dos contos. O primeiro deles foi "Exu torna-se amigo predileto de Orunmilá" (PRANDI, 2018, p. 70). Esse conto serviu para demonstrar que os orixás têm personalidades diferentes e valores iguais aos dos seres humanos. Os alunos concordaram que as pessoas são diferentes umas das outras e pontuaram que isso é um direito das pessoas e que é necessário convivermos com isso. 
O próximo conto lido foi "Otim esconde que nasceu com quatro seios" (Ibid., p. 144), cuja prova de amor de um pai para filha deu origem ao rio Otim e a montanha Oquê. Esse conto serviu como paralelo ao conhecimento científico, que compreende que um rio ou uma montanha, que atua como uma divisora de bacias hidrográficas, são resultados de interações geológicas no decorrer de milhões a bilhões de anos. Os alunos ficaram emocionados pelo conto e perguntaram se é verdadeira a estória e se o rio e a montanha existiam de verdade. Também foi lido o conto "Oiá transforma-se no rio Níger" (Ibid., p. 302), cujo enredo é muito similar ao conto anterior protagonizado por Otim e Oquê, porém com outras personagens, Oiá e Xangô, esposa e marido. A estória também trouxe comentários emocionados e perguntas sobre o Rio Níger. Porém, foi dada aos alunos a orientação para que eles ouvissem então o último conto, "Oiá cria um rio dum pedaço de pano preto" (Ibid., p. 301), no qual foi contada a história do Rio Níger, importante rio da África. Os alunos perguntaram novamente se o rio Níger existia, o porquê de um pano preto, etc. Tendo em vista as dúvidas dos alunos, com o auxílio de um mapa-múndi foram expostas as localizações do Rio Níger e dos países africanos que são drenados por sua bacia hidrográfica. Também explicadas as importâncias econômica e cultural do rio para os povos africanos, os problemas ambientais etc. O pano preto de Oiá foi relacionado ao fato de que as águas do Rio Níger são turvas, característica comum em rios tropicais como ele e os do Brasil, dentre eles o Rio Meia Ponte, conhecido por todos por banhar o bairro da escola campo.

Encerrada a leitura dos contos, os estudantes disseram que gostaram bastante deles e de conhecer melhor sobre as crenças das outras religiões. Disseram que aulas como aquelas, falando de mitos trazidos de outras culturas e de outras religiões, deveriam acontecer mais vezes. Também que a escola poderia trazer alguém de alguma religião de matriz africana para dar palestras a todos explicando em que acreditam e tirando as dúvidas dos alunos. Eles foram informados que em razão do cronograma bimestral seria difícil a visita de um palestrante, mas que seria analisada uma data junto a coordenação pedagógica. Contudo, após a análise, foi confirmada a inviabilidade de uma palestra.

\section{REFLEXÕES APÓS AS AULAS}

No bairro do Jardim Novo Mundo, no qual está localizada a escola campo, existem pelo menos dois terreiros. Por existirem, é provável que se encontre na escola algum estudante que frequente algum deles. Contudo, nenhum aluno se declarou adepto de alguma religião de matriz africana antes, durante ou após as aulas. No máximo alguns deles identificaram ter algum conhecido que faça parte de alguma. Via de regra, foi possível notar inicialmente que muitos alunos possuíam ideias equivocadas a respeito dessas religiões, o que culminavam em preconceitos diversos.

Porém, algumas exposições, como as sobre o que é uma macumba, um orixá, o nome e a diferença entre o Candomblé e a Umbanda, enfim, levaram os estudantes a produzirem reflexões e se atentarem a aspectos que desconheciam. Eles também se mostraram receptivos ao novo através da atenção e da curiosidade com as quais ouviram os contos e as exposições do professor. Fizeram muitas perguntas e afirmações no decorrer das aulas. Os contos que envolvem Oquê e Otim e Oiá e Xangô (PRANDI, 2018) 
BORBA, W. G.

foram os que chamaram mais a atenção e produziram admiração, por dizerem que um rio e uma montanha nasceram como provas de um amor incondicional de um pai para a filha e de uma esposa para o marido, respectivamente.

A leitura dos contos contribuiu para que os estudantes se tornassem mais críticos em relação às próprias falas e às de seus colegas, o que foi percebido pela redução no decorrer das aulas das falas que repercutiam ideias equivocadas e preconceituosas. Os contos despertaram também admiração em relação aos orixás, alguém disse "um dia vou encontrar minha Oiá", bem como contribuiu para incentivar pensamentos mais tolerantes e plurais como, aceitar a diferença, entender que as religiões devem ser respeitadas, que é necessário conhecer algo antes de criticar etc. Os contos contribuíram também para reforçar o entendimento a respeito de bacias hidrográficas, principalmente ao se falar da bacia do Rio Níger. Foi perceptível nas falas que os estudantes no geral estavam dominando conceitos como área de drenagem, nascente, afluentes, além da importância que o relevo, as montanhas no caso, tem na constituição de uma bacia.

\section{CONSIDERAÇÕES FINAIS}

O Brasil é um país diverso e a pluralidade é reconhecida em sua Constituição, assim como outros direitos, como as liberdades de pensamento, expressão e religiosa (BRASIL, 1988). Especificamente, a liberdade religiosa está prevista em lei desde a fundação da República (BRASIL, 1891). Mesmo assim são comuns e crônicos os atos de violência contra a pluralidade e as liberdades, principalmente a religiosa quando esta diz respeito às religiões de matriz africana. Os atos têm como fundamentos o desconhecimento que cerca essas religiões, a disputa por fiéis empreendidas por algumas igrejas neopentecostais, mas também o racismo histórico, estrutural, velado e crônico no Brasil (CAMPOS, 2015; HALLEY, 2014; LIMA et al., 2016; PAULO, 2015; PRANDI, 2004; SILVA, 2007; TEIXEIRA, 2009).

Uma resposta aos atos de intolerância religiosa e de cunho racista é a educação, um direito social garantido a todos e que deve estar calcada nos valores constitucionais, como a pluralidade, e que tem como propósito formar para o exercício profissional e para o exercício da cidadania. Essa mesma educação tem como premissa a liberdade de pesquisar, divulgar e ensinar o conhecimento, os saberes e a arte (BRASIL, 1988, 1996). Mesmo assim alguns temas, por mais importantes que eles sejam, foram ignorados pelos currículos escolares de maneira crônica, precisando no final das contas de uma lei obrigando o ensino dos mesmos, caso dos temas envolvendo a África e os afro-brasileiros (BRASIL, 2003). Apesar de toda a legislação existente em favor desses aspectos educacionais e individuais, hoje, via de regra, os alunos das religiões de matriz africana ainda são resistentes em assumir suas identidades religiosas no espaço escolar (CAMPOS, 2015; LIMA et al., 2016; PAULO, 2015) e conforme foi notado nas vivências pedagógicas narradas neste trabalho: alunos que se assumem como de alguma religião com maior aceitação social, no caso evangélica, mas que frequentam o terreiro, ou alunos que se assumem apenas como evangélicos ou católicos em uma escola cujo bairro possui terreiros.

A intervenção do professor segue obviamente a legislação, mas essa intervenção demanda também a pesquisa tanto para respaldar quanto às próprias leis como para realizar o planejamento das aulas, produzir um novo material didático, a despeito do livro, 
por exemplo. Tendo em vista o novo material, o livro de contos Mitologia dos Orixás (PRANDI, 2018), ao se falar das bacias hidrográficas o processo de ensino-aprendizado foi potencializado. Primeiro, porque reforçou todos os conceitos já estudados na sequência de aulas, o que foi demonstrado quando se falou da bacia do Rio Níger. Depois, porque os contos contribuíram para tornar as aulas mais atraentes e menos enfadonhas. Foi notório que alguns alunos ficaram sensibilizados pelos contos que envolviam as provas de amor. E, também, porque o livro se mostrou uma fonte de conhecimentos uteis para os objetivos das aulas no que se refere às bacias hidrográficas e às religiões de matriz africana. Foi também acessível e prazerosa. Talvez com um texto técnico sobre um orixá e copiado do site de alguma comunidade afro-religiosa a aula perderia o contexto, podendo culminar em algo desconectado e de viés conteudista. Por fim, porque abriu precedente para que fossem abordados determinados assuntos como as religiões de matriz africana, o preconceito e a intolerância religiosa.

Durante as aulas os estudantes ouviram muitas falas do professor, porém demonstraram grande autonomia expondo e contrapondo ideias, produzindo sínteses e se colocando como sujeitos. Pode-se notar que no caso exposto a literatura, através da Mitologia dos Orixás (PRANDI, 2018), mostrou ainda mais aspectos positivos do que os demonstrados por Martins (2017). Entretanto, com tanta lei e com tanta literatura, percebe-se que falta muito para que as religiões afro-brasileiras tenham o mesmo tratamento que as religiões socialmente aceitas, catolicismo e protestantismo, possuem entre os muros da escola (CAMPOS, 2015; LIMA et al., 2016; PAULO, 2015), principalmente os muros sociais.

\title{
ORISHA MYTHOLOGY IN RIVER BASINS LESSONS: TEACHING AND DISCUSSIONS ABOUT RELIGIOUS INTOLERENCE
}

\begin{abstract}
This paper tells about Geography lessons in Elementary School in a public school. The central content included river basins and as cross-cutting theme the orisha mythology, the religions of African origin and the religious intolerance. The objectives include the literature as ally to teaching river basins, especially the orishas short stories, and to talk about the cross-cutting themes, enhancing the respect and the religious tolerance. There was a review on academic productions, applicable legislation, normative documents, and reportages. Also, it included the didactic book and the Mitologia dos Orixás (PRANDI, 2018). The conclusion reached is the literature, across the short stories, optimized the Geography lessons, enhanced the concepts about river basins and encouraged talks about cross-cutting themes.
\end{abstract}

KEYWORDS: River Basins. Orisha Mythology. Religions of African Origin. Religious Intolerance. 


\section{MITOLOGÍA DE LOS ORISHÁS EN AULAS SOBRE CUENCAS HIDROGRAFÍCAS: EL ENSEÑO Y LOS DIÁLOGOS SOBRE LA INTOLERÂNCIA RELIGIOSA}

RESUMEN: Este trabajo narra clases de Geografía en una escuela primaria pública. El contenido principal involucró las cuencas hidrográficas y como temas transversales la mitología de los orishas, las religiones de raíces africanas y la intolerancia religiosa. Los objetivos consisten en combinar la literatura con la enseñanza de cuencas hidrográficas, concretamente con cuentos sobre los orishas, y la promoción de diálogos sobre los temas transversales antes mencionados, apoyando el respeto y la tolerancia religiosa en la escuela. Se realizó una revisión de la producción académica, la legislación, los documentos normativos y los informes. También del libro de texto y la Mitologia dos Orixás (PRANDI, 2018). Se puede ver que la literatura, por los cuentos, potenció las clases de Geografía, reforzando los conceptos sobre cuencas hidrográficas y abriendo espacio para la discusión de temas transversales.

PALABRAS CLAVE: Cuencas Hidrográficas. Mitología de los orishas. Religiones de raíces africanas. Intolerancia Religiosa.

\section{NOTAS}

1) Segmentos, que conforme reportagem, defendem projetos como o Escola Sem Partido, que pretende impedir os professores abordarem temas como política, sexualidade e a religião. Assuntos que os apoiadores do projeto defendem serem exclusivos para os pais dos alunos e inadequados para a escola (BBC NEWS, 2018).

2) Na coletânea "Expedições Geográficas" o livro é dividido em unidades e em capítulos, que neste caso são chamados pelos autores de Percursos.

3) Sigla inglesa para rhythm and poetry ou ritmo e poesia em tradução livre.

4) Dois caipiras, um de Goiás e outro de Minas Gerais, foram pescar em uma ponte sobre o Rio Paranaíba, que divide os territórios dos dois estados. Passado algum tempo após a pescaria começar, apenas o goiano estava fisgando enquanto o mineiro pescou nada. Irritado, o mineiro olhou em direção ao goiano e ao seu lado da ponte e perguntou ao colega se ele sabia o que era $\mathrm{GO}$, que estava escrito na placa de sinalização. O goiano empolgado com a pescaria respondeu sem pensar: "Não sei não, siô!" O mineiro ainda mais irritado devolveu: "GO significa que do seu lado só tem Gonorante!" O goiano ouviu calado e após algum tempinho olhou para o lado do mineiro, viu a placa daquele lado, juntou a tralha e os peixes e retrucou com outra pergunta: "E ocê, sabe o que é MG?" O mineiro, que era como o goiano, respondeu: "Não, nadinha!" Então o pescador goiano respondeu: "MG significa que do seu lado só tem Mais Gonorante!"

5) Exemplos: "Coisa do Diabo", "Eles sacrificam as pessoas", "Fazem ritual de magia negra”, "Tenho medo do Exu Caveirinha me pegar", "Deus me livre", "Tenho medo de fazer macumba pra mim". Nenhuma das falas são ipsis litteris, uma vez que não houve registro escrito ou gravação, apenas como são lembradas.

\section{REFERÊNCIAS}

ADAS, M.; ADAS, S. Expedições de Geográficas. 6 Ano. São Paulo: Moderna, $2015 a$. 
ADAS, M.; ADAS, S. Expedições de Geográficas: 70 Ano. São Paulo: Moderna: 2015b.

BBC NEWS. Mesmo sem lei, Escola Sem Partido se espalha pelo país e já afeta rotina nas salas de aula. 2018. Disponível em: <https://www.bbc.com/portuguese/brasil46006167?ocid=wsportuguese.social.sponsored-post.google.SMP(AEP)EscolaSemPartidoGG-Brasil.nneed6.mktg>. Acesso em: 25 nov. 2018.

BERGMANN, M.; PEDROZO, C. S. Explorando a bacia hidrográfica na escola: contribuições à educação ambiental. Ciência e Educação, v. 14, n. 3, p. 537-553, 2008. Disponível em: $<$ https://dialnet.unirioja.es/descarga/articulo/5274270.pdf>. Acesso em 03 maio 2019.

BRASIL. Constitução Federal. 05 de outubro de 1988.

BRASIL. Constitução Federal. 24 de fevereiro de 1891.

BRASIL. Constitução Federal. Lei 10.639.09 de janeiro de 2003.

BRASIL. Constitução Federal. Lei 9.394. 20 de dezembro de 1996.

BRASIL. Constitução Federal. Parâmetros Curriculares Nacionais: Geografia (5a a $8^{\mathrm{a}}$ Séries). Brasília: MEC, 1998.

CAMPOS, A. C. Religião de matriz africana: um olhar de dentro da sala de aula. In.: CONGRESSO DE CIÊNCIA E TECNOLOGIA DA PUC GOIÁS, 1., 2015. Anais... Disponível em: $<$ http://pucgoias.edu.br/ucg/prope/pesquisa/anais/2015/PDF/I_Coloquio_Bullying_Sub merso/Textos_completos/Grupo\%20de\%20trabalho\%204/GT4_religiaodematrizafricana .pdf>. Acesso em: 26 nov. 2018.

GOIÁS. Secretaria de Estado da Educação de Goiás. Currículo de Referência da Rede Estadual de Goiás. Versão Experimental. 2011. Disponível em:

<http://www.seduc.go.gov.br/imprensa/documentos/arquivos/Curr\%C3\%ADculo\%20R efer\%C3\%AAncia/Curr\%C3\%ADculo\%20Refer\%C3\%AAncia\%20da\%20Rede\%20Estadual \%20de\%20Educa\%C3\%A7\%C3\%A30\%20de\%20Goi\%C3\%A1s!.pdf>. Acesso em: 25 nov. 2018.

HALLEY, M. B. Onde mora Xangô? Fatores de localização de terreiros afro-religiosos às margens do rio Água Fria - Recife (séculos XIX-XX). Tempo - Técnica - Território, v. 5, n.1, p. 29-54, 2014. Disponível em:

<http://periodicos.unb.br/index.php/ciga/article/view/19534>. Acesso em: 25 nov. 2018.

LIMA, J. P.; ROCHA, J. G.; ROCHA, M. P. J. G. da; PORTO, M. Intolerância religiosa em escolas públicas no Rio de Janeiro. Educação, v. 41, n. 3, p. 709-718, 2016. Disponível em: $<$ https://periodicos.ufsm.br/reveducacao/article/view/22100/pdf>. Acesso em: 03 maio 2019.

MARTINS, I. do M. M. A geografia das cidades e das transformações urbanas na obra de Fiódor Dostoiévski: o espaço em Os Irmãos Karamázov. Boletim Goiano de Geografia, v. 37, n.3, p. 509-527, 2017. Disponível em:

<https://revistas.ufg.br/bgg/article/view/50768/24792>. Acesso em: 25 nov. 2018. 
BORBA, W. G.

PAULO, A. F. de. Religiões afro-brasileiras e a educação: intolerância no ensino de hitória. Revista Espaço Acadêmico, n. 174, p. 67-78, 2015.

PRANDI, R. Mitologia dos Orixás. São Paulo: Companhia das Letras, 2018.

PRANDI, R. O Brasil com axé: candomblé e umbanda no mercado religioso. Estudos Avançados, v. 18, n. 52, p. 22-238, 2004. Disponível em:

$<$ http://www.scielo.br/scielo.php?script=sci arttext\&pid=S0103-40142004000300015>. Acesso em: 02 maio 2019.

SILVA, V. G. da S. Neopentecostalismo e religiões afro-brasileiras: significado do ataque aos símbolos da herança religiosa africana no Brasil contemporaneo. Mana, v. 13, n. 1, p. 207-236, 2007. Disponível em: <http://www.scielo.br/pdf/mana/v13n1/a08v13n1.pdf>. Acesso em: 02 maio 2019.

SUPER INTESSANTE. País registra cada vez mais agressões e quebras de terreiros. Disponivel em: $<$ https://super.abril.com.br/sociedade/pais-registra-cada-vez-maisagressoes-e-quebras-de-terreiro/>. Acesso em: 25 nov. 2018.

TEIXEIRA, J. P. Paisagens e Territórios Afro-Brasileiros no Espaço Urbano: Terreiros de Candomblé em Goiânia. 2009. Dissertação (Mestrado em Geografia) - Instituto Estudos Sócio-Ambientais, Universidade Federal de Goiás, Goiânia, 2009. Disponível em: <https://repositorio.bc.ufg.br/tede/handle/tde/1903>. Acesso em: 25 nov. 2018.

Wellington Gabriel de Borba: Formado em Geografia pela Universidade Federal de Goiás, Campus Samambaia - Goiânia-GO. Especialista em Educação Inclusiva com Ênfase em Antendimento Educacional Especializado pela Faculdade Brasileira de Cultura - FABEC em Goiânia-GO. Professor de Geografia do Ensino Básico na Secretaria de Educação Cultura e Esportes de Goiás desde 2010.

ORCID: https://orcid.org/0000-0003-4293-8438

E-mail:wellingtonborba@smail.com

Este periódico utiliza a licença Creative Commons Attribution 3.0, para periódicos de acesso aberto (Open Archives Iniciative - OAl). 